Iran Journal of Nursing (IJN)

Vol 31, No. 116, Feb 2019: 61- 74

\title{
Successful Ageing in the Dimensions of Life Satisfaction and Perception of Ageing in the Iranian Elderly Adults Referring to the Health Center in the West of Tehran, Iran
}

\author{
Fereshteh Abolhasani ${ }^{1},{ }^{*}$ Farideh Bastani $^{2}$
}

\begin{abstract}
Background \& Aims: Achieving the goals of successful ageing is considered to be an effective strategy for the promotion of health in the elderly. The concept of healthy and successful ageing encompasses significant components, including life satisfaction, positive perception of the changes in old age, longevity, lack of disability, and independence in life. The present study aimed to assess successful ageing in terms of life satisfaction and perception of ageing in the elderly patients referring to the health center in the west of Tehran, Iran.

Materials \& Methods: This cross-sectional, descriptive study was conducted on 200 elderly individuals referring to the health center in the west of Tehran, Iran in 2017, who were selected via convenience sampling based on the inclusion criteria. Data were collected using the abbreviated mental test (AMT), a demographic questionnaire, LSI-Z life satisfaction inventory, and ageing perception questionnaire (B-APQ). The questionnaires were completed via face-to-face interviews (15 minutes). Data analysis was performed in SPSS version 20 using independent $t$-test and one-way analysis of variance (ANOVA), as well as descriptive and inferential statistics at the significance level of $\mathrm{P} \leq 0.05$.

Results: The mean score of life satisfaction in the participants was $15.2 \pm 2.2$, which indicated the high level of life satisfaction. Significant correlations were observed between life satisfaction and age, gender, education level, economic status, occupation status, marriage, independence in daily tasks, and health and psychological status. In addition, the mean score of the perception of ageing in the subjects was 53.08 \pm 3.9 , and significant correlations were observed between this variable and age, marital status, education level, life status, economic status, health status, and independence in daily tasks $(\mathrm{P}<0.05)$.

Conclusion: Considering that the participants in this research were mostly selected from the young elderly (age: 60-75 years) and had high life satisfaction and positive perceptions toward their ageing process, it seems that there is a positive association with life management strategies and healthy lifestyle. Therefore, the main slogan to achieve the goals of successful ageing would be to 'add life to the life year, rather than adding life years to life'.
\end{abstract}

Keywords: Aging, Life Satisfaction, Perception

\section{Conflict of Interest: No}

How to Cite: Abolhasani F, Bastani F. Successful Ageing in the Dimensions of Life Satisfaction and Perception of Ageing in the Iranian Elderly Adults Referring to the Health Center in the West of Tehran, Iran. Iran Journal of Nursing. 2019; 31(116):61-74.

Received: 20 Nov 2018

Accepted: 19 Feb 2019

\footnotetext{
1. MS Student in Geriatric Nursing, School of Nursing and Midwifery, Iran University of Medical Sciences, Tehran, Iran

2. Professor, Department of Public Health Nursing and Geriatrics, School of Nursing and Midwifery, Iran University of Medical Sciences, Tehran, Iran (*Corresponding author) Tel: $02143651800 \quad$ Email: bastani.f@iums.ac.ir
} 


\title{
سالمندى موفق در بعد رضايت از زندكى و درى از سالمندى در سالمندان مراجعه كننده به مركز بهداشت فرب تهران
}

\author{
فرشته ابوالحسنى '، **ريده باستانى
}

\begin{abstract}
جكيله
زمينه و هدف: يكى از مؤثرترين راهبردهاى ارتقاء سلامت در سالمندان، رسيدن به اهداف "سالمندى موفق" است. مفهوم "سالمندى موفق و سالم"

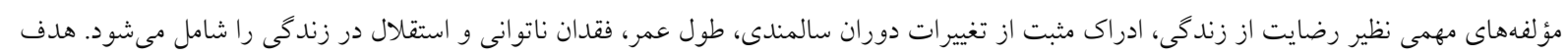

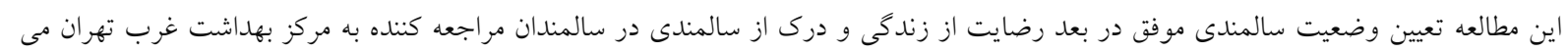

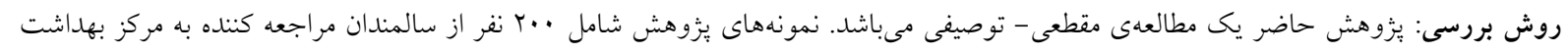

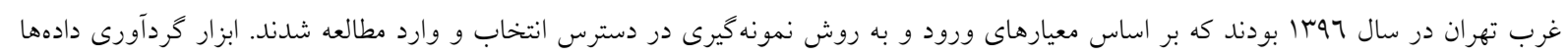

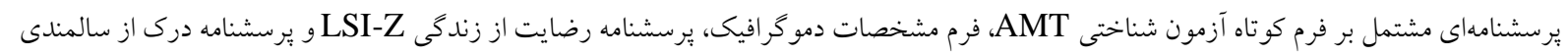

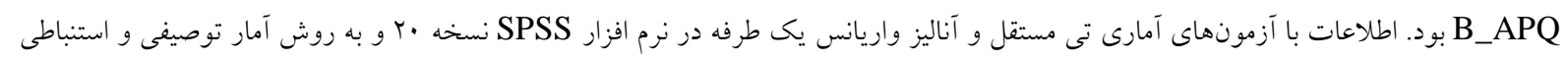
در سطح معنى دارى P

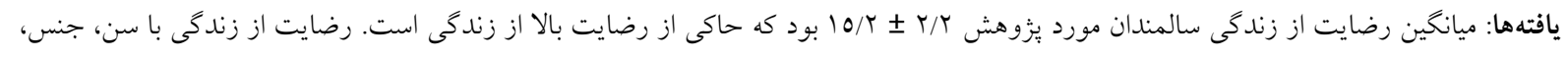

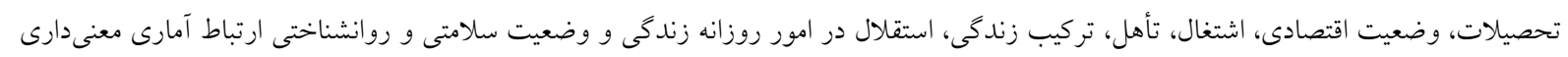

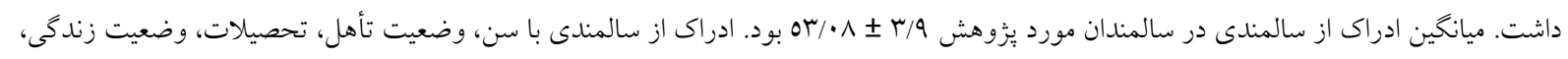

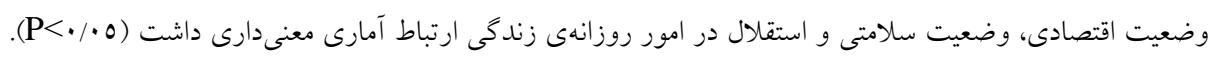

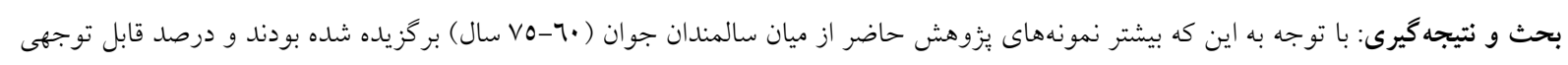

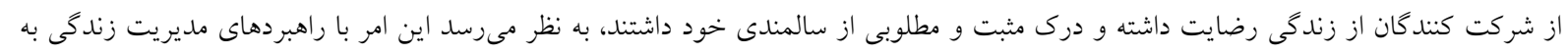

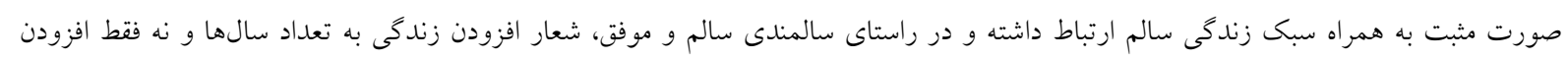
تعداد سالها به زندكى مورد تأكيد قرار مى گيرد.

كليد وازهها: سالمندى، رضايت از زندگى، درى

تعارض منافع: ندارد تاريخ دريافت: تاريخ يذيرش: ·

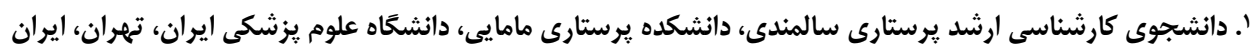

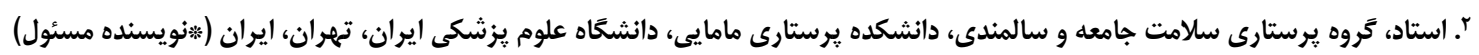


يبامدها و موفقيت ها به اشكال متنوعى مىشود (V). سالمندى

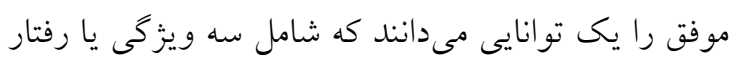
كليدى است ا- كاهش احتمال بيمارى Y- كنش بالاى ذهنى و بدنى بـ سازگارى با تنشها و بحرانهاى زندكى (^). سالمندى موفق سازگارى سالمندان با تغييرات

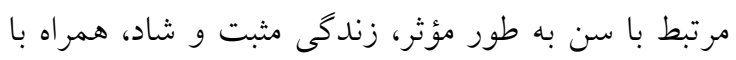

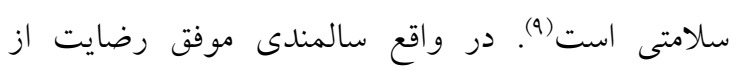
زندكى، طول عمر، فقدان ناتوانى، درى مثبت از تغييرات

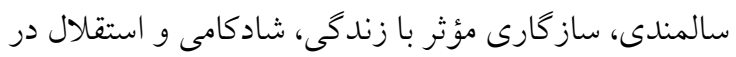

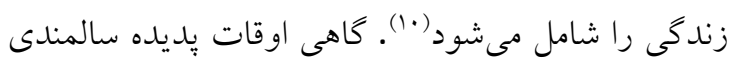

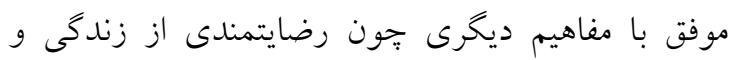

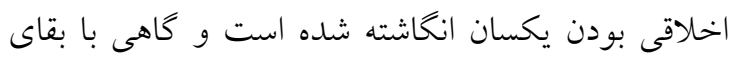

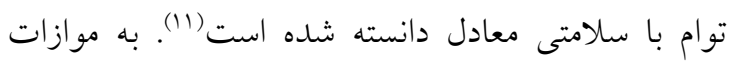

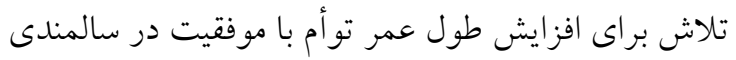

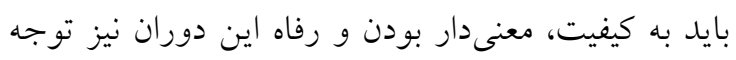

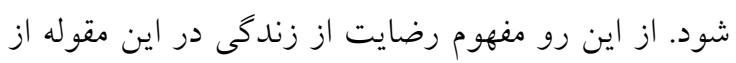

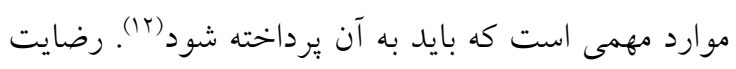

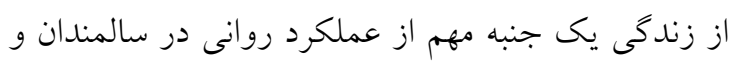

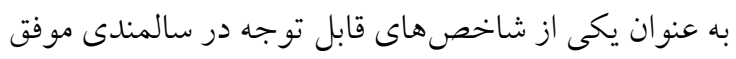

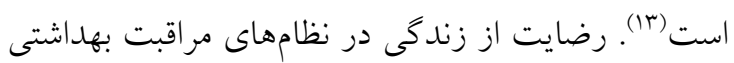

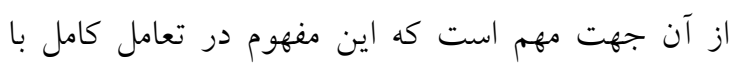

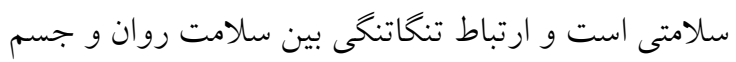

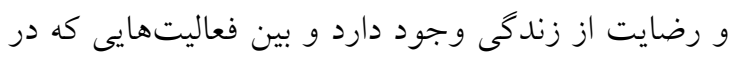

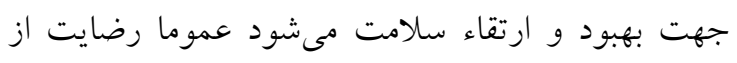

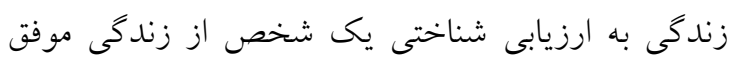

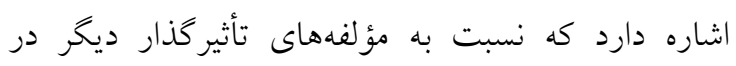
سالمندى موفق داراى اهميت بيشترى است. بنابراين

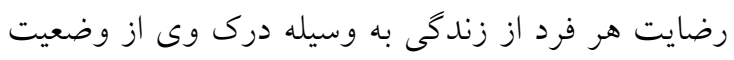

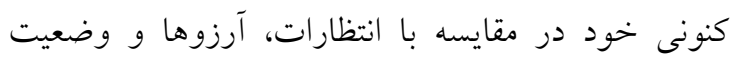

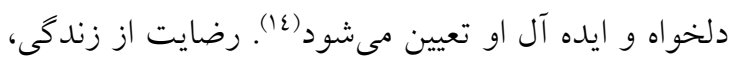

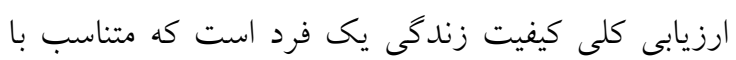

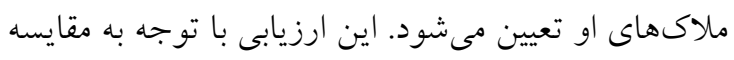

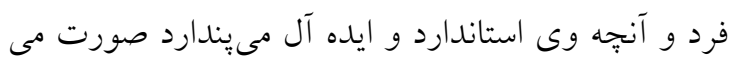

\section{مقدمه}

افزايش روز افزون جمعيت سالمندان در دنيا تا اندازهاى است كه از آن به عنوان انقلاب ساكت ياد شده است (1). كزارش مىشود كه در •ع سال آينده جمعيت بالاى 70

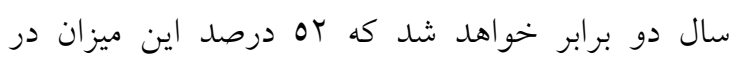
كشورهاى آسيايى و •ع درصد آن در كشورهاى بيشرفئه

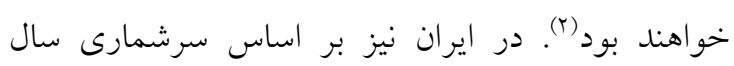

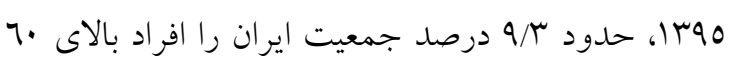

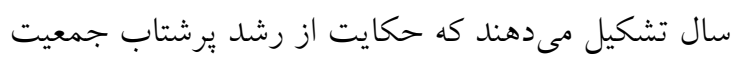

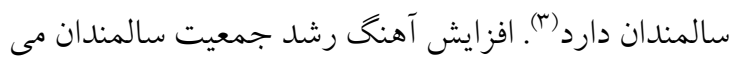

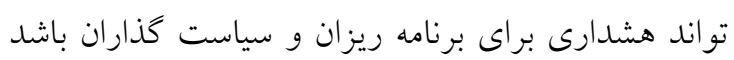

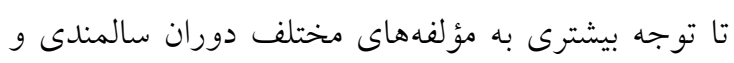

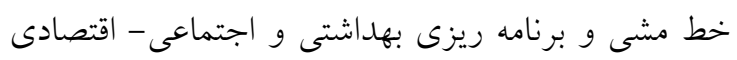

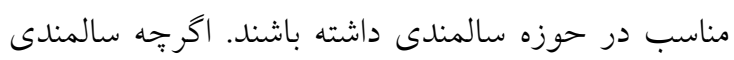

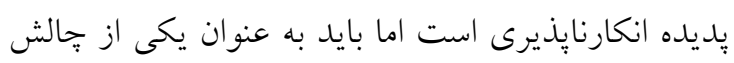
هاى آينده به صورت ويزهه به آن يرداخته شود آنائ.

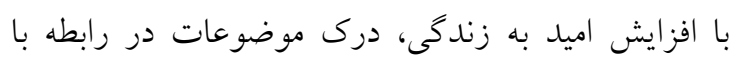

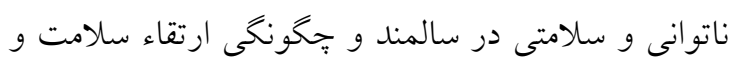

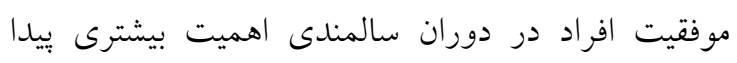

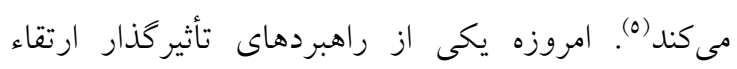

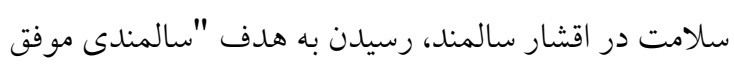

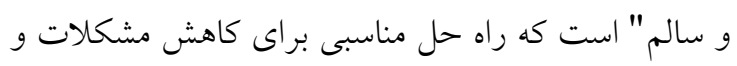

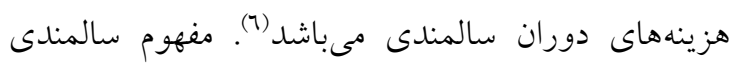

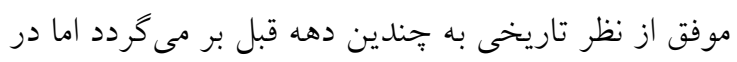

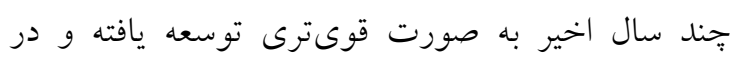

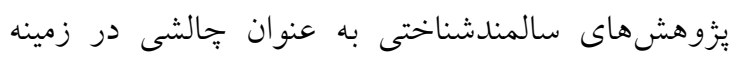

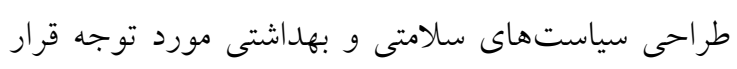

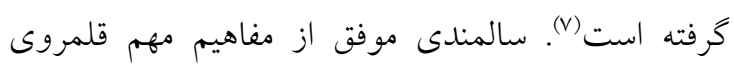

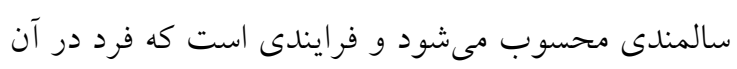

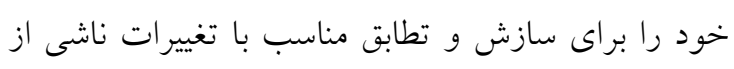

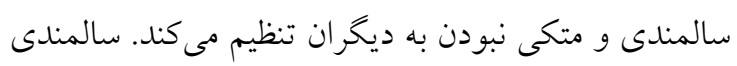

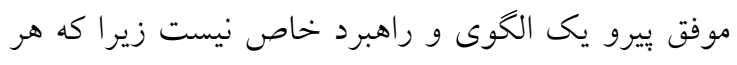

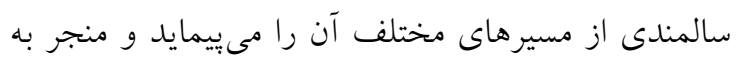


حاضر با هدف تعيين سالمندى موفق در بعد رضايت از زندكى و ادراك از سالمندى صورت كرفته است.

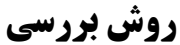

يُزوهش حاضر از نوع توصيفى (مقطع) است. جامعه

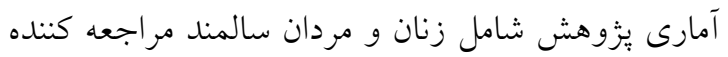

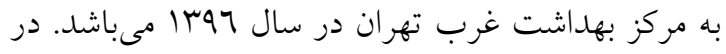
اين مطالعه .Y. نفر سالمند به روش در دسترس انتخاب شدند. به اين ترتيب كه يزوهشكر با مراجعه روزانه به مركز بهداشت غرب تهران نمونههايى را كه واجد شرايط بودند به مطالعه دعوت نمود. شرايط ورود سالمندان به مطالعه شامل سن •T تا Vo سال (طبق طبقه بندى WHO كه سالمندان جوان مد نظر بودند)، مبتلا نبودن سالمند به زوال عقل (بر اساس يرونده بهداشتى يا بنا به اظهار مراقبين اصلى)، داشتن سواد خواندن و نوشتن، نداشتن

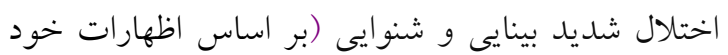
سالمند) و كسب نمره وضعيت شناختى هفت و بالاتر در مقياس Abbreviated Mental Test) AMT) از نظر ومعند نداشتن اختلال در عملكرد شناختى بود.

IR. ) ئزوهشخر يس از كسب مجوز از كميته اخلاق (IUMS.REC 1396.951158001 22/21/6931 و معاونت يزوهشى دانشگاه علوم بزشكى ايران به مركز

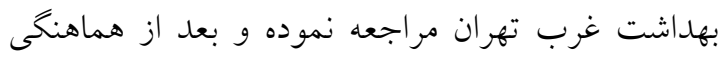

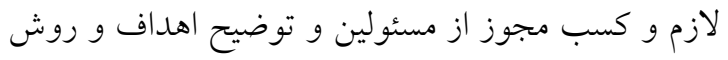

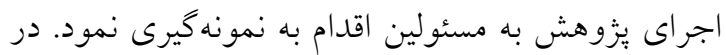

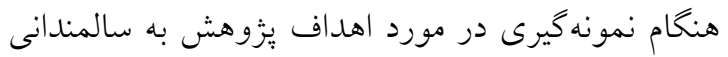

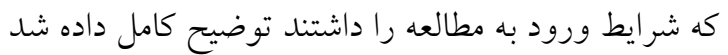
و در صورت تمايل براى شركت در يزوهش، فرم رضايت

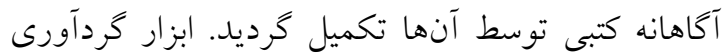
اطلاعات شامل فرم مشخصات جمعيت شناختى (سن، جنس، سطح تحصيلات، وضعيت تأهل، وضعيت اقتصادى، وضعيت اشتغال، وضعيت سلامت فعلى، بيمارى هاى زمينهاى، استقلال در انجام امور روزانه زندگى و
كيرد. همين يندار و ارزيابى فرد است كه مفهوم بهزيستى و رضايت از زندكى رامى سازد (10).

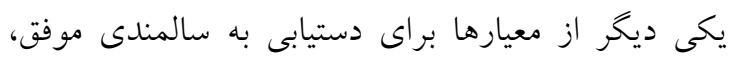

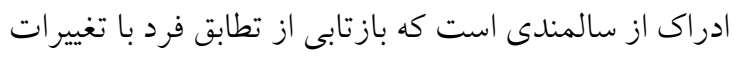

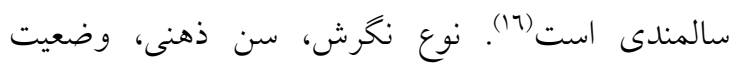

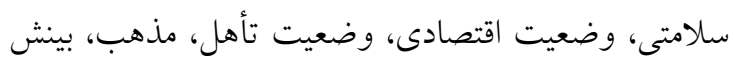
در زمينه سالمندى، ميزان رضايت از زندكى و سالخوردگى، ميزان باور به انجام وظايف بدون نظارت و مستقل و عوامل اجتماعى نيز تحت عنوان ادراك از سالمندى بررسى شده

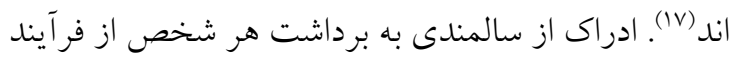
سالمندى خود در زمينه فرهنكى - اجتماعى اطلاق مى شود. مىتوان كفت توجه به تمام جنبههاى آكَاهى، درك، تجربه، ارزيابى، تفسير و شناخت مراحل بير شدن مىتواند به شناخت ابعاد مختلف روانشناختى يديده سالمندى منتهى لئى

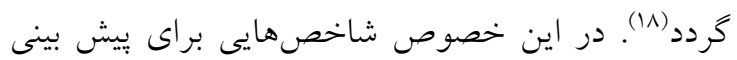

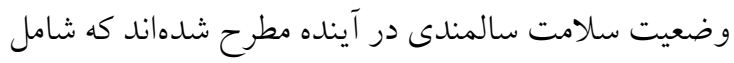

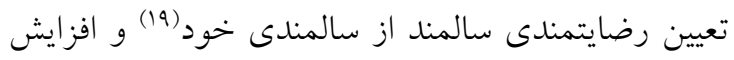

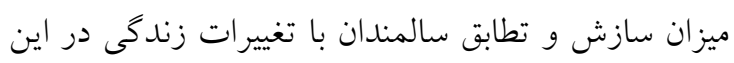
مرحله است كه با طول عمر به لحاظ كمى و كيفى مرتبط

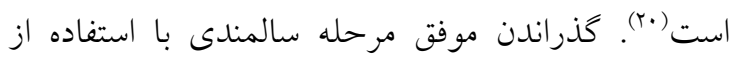
نتيجه مشترى تجارب و دانش فرد، منجر به كارگيرى راهبرد مقابلهاى مناسب در سالمندان مىشود. از سوى ديخر

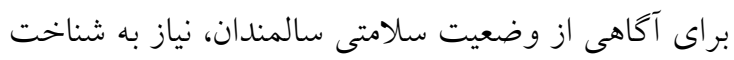

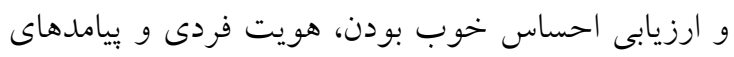
رفتارى فرد در جامعه، تجربه و درى سالمند از فرايند بيرى مىباشد (r). سبرى كردن دوران سالمندى با كمترين ناتوانى و بيمارى،

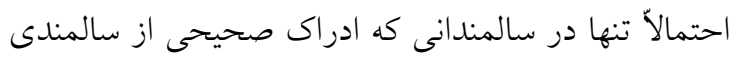
دارند قابل دستيابى و مشاهده است. يُنداره مثبت يا به تعبيرى ادراك مثبت از خود به دستيابى سلامتى ذهنى، رضايت از زندكى و خود امتيازدهى سلامتى منجر

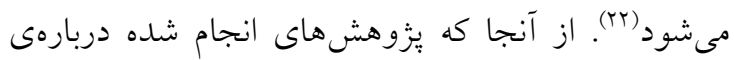

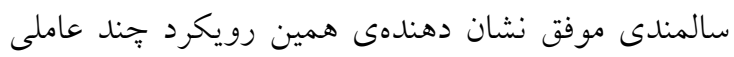

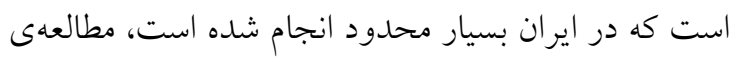


كه روايى صورى مقياس طبق نظر اساتيد فن مورد تأييد

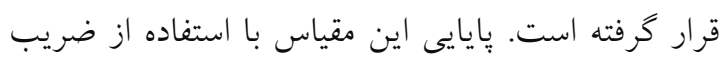

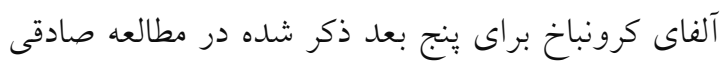

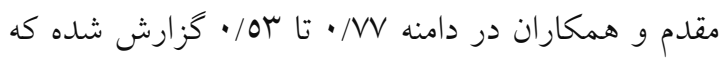

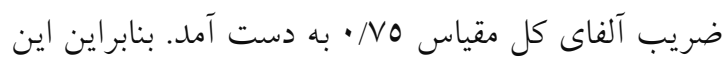
مقياس از بايايى مناسبى برخوردار بوده است (17). برسشنامه سالمندى موفق (در بعد رضايت از زندگى بائى):

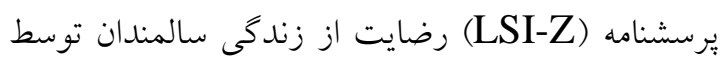
(1979) Wood, Wylieis \& Sheafor است. اين مقياس rا سئوالى فرم كوتاهى است كه در آن

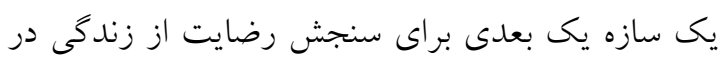

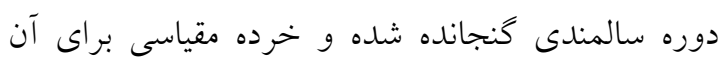
تعريف نشده است. از مجموع سئوالات، ينج سئوال بار

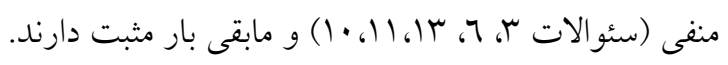
به هر يك از سئوالات در قالب گزينههاى نمىدانم امتياز يك، مخالف امتياز صفر و موافق امتياز دو داده مىشود. جهت نمره كذارى از سيستم (·-Y) استفاده شده است.

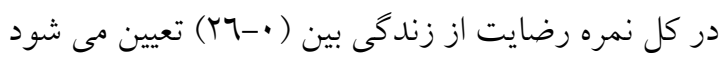

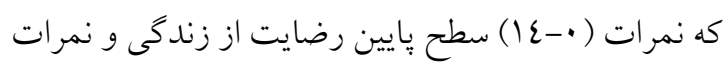

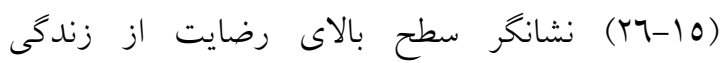
هستنل (ro)

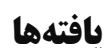

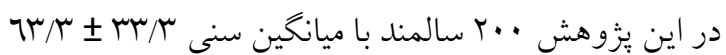

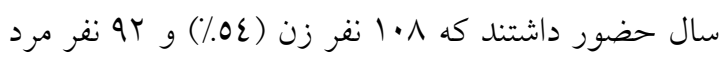

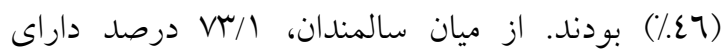
تحصيلات زير دييلم، Y T/9 درصد دييلم و دو درصد

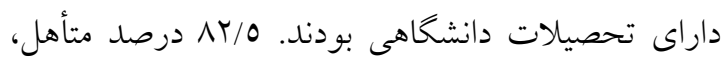

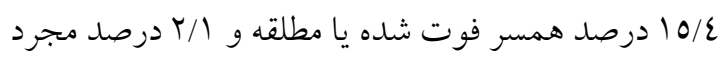
بودند. همجنين 91 درصد آنها در انجام امور روزانه زندكى مستقل و تنها دو درصد متكى به ديكران بودند. درصد نيز وضعيت سلامتى خود را همانند همسالان، درصد بهتر از همسالان و عا درصد بدتر از همسالان

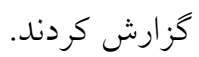

وضعيت روانشناختى) از طريق مصاحبه تكميل شد. فرم

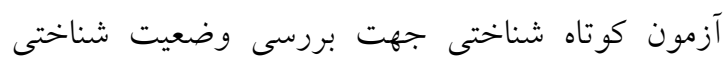

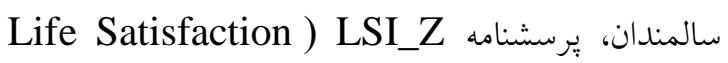
جهت بررسى رضايت از زندگى و يرسشنامه (Index-Z Brief-Aging Perception ) B_APQ براى تعيين ادراى از سالمندى (Questionnaire استفاده شد. تكميل يرسشنامها به صورت مصاحبه حضورى در مدت زمان 10 دقيقه انجام شد.

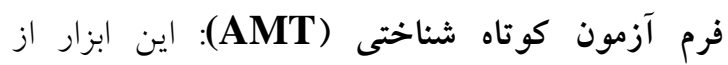

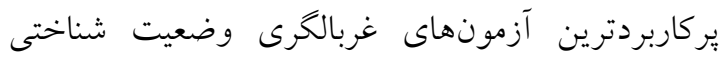
سالمندان در جهان است كه حاوى ·ل سئوال است. اين

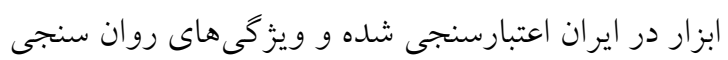

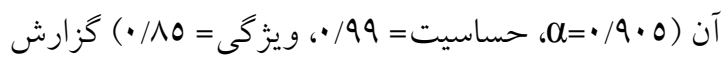

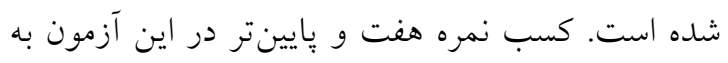
معنى وجود اختلال شناختى است و حداكثر امتياز آن نمره

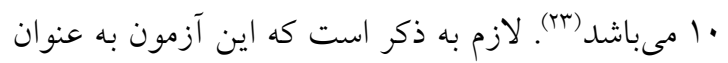

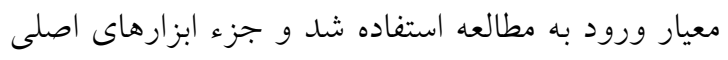
مطالعه تلقى نمى شود. برسشنامه سالمندى موفق (در بعد ادراك از سالمندى):

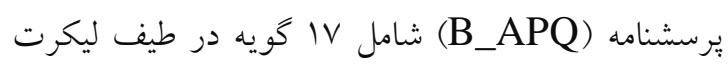
است (זع). از نظر كمى، بنج بعد اين بِرسشنامه كه كلاً در

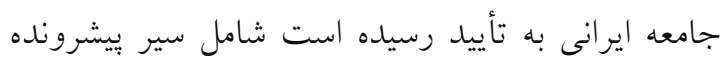

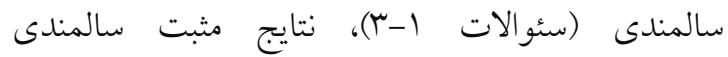

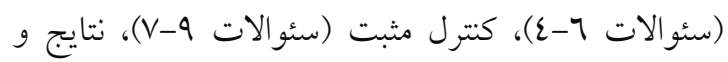

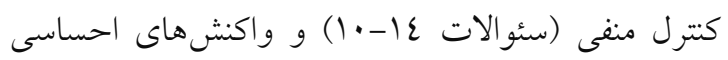

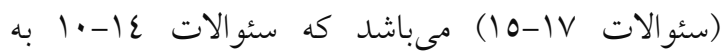
صورت معكوس نمره دهى مىشوند (كاملاً مخالف با نمره

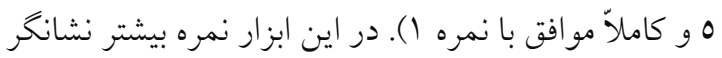

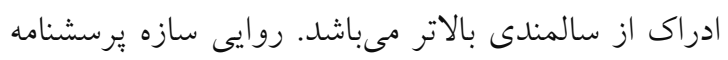

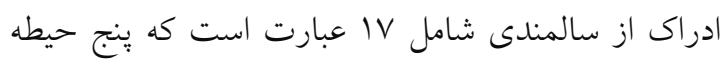

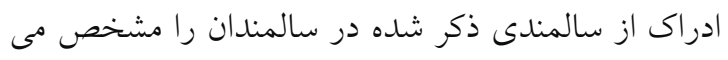

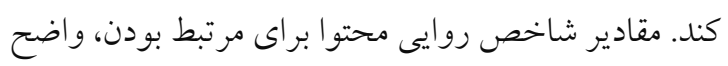

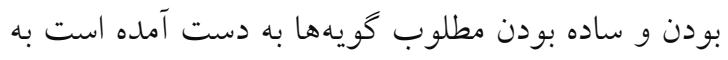
طورى كه شاخص روايى محتواى كل مقياس 97/ • بود 
جدول شماره (: مشخصات جمعيت شناختى نمونههاى يزوهش

\begin{tabular}{|c|c|c|c|}
\hline درصد & فراوانى & \multicolumn{2}{|c|}{ متغير } \\
\hline W/o & irv & $7 \cdot-7 \varepsilon$ & \\
\hline r) & $\varepsilon r$ & $70-79$ & سن \\
\hline $1 \cdot 10$ & r) & $V \cdot-V_{0}$ & \\
\hline$\varepsilon\rceil$ & 94 & 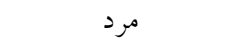 & جنسيت \\
\hline or & $1 \cdot 1$ & زن ان & \\
\hline$V \Psi / I$ & $1 \varepsilon V$ & زيردييلم & \\
\hline$r \varepsilon / q$ & $\varepsilon 9$ & دييلم & تحصيلات \\
\hline r & $\varepsilon$ & تحصيلات دانشگاهى & \\
\hline$\Lambda r / 0$ & 170 & متأهل & \\
\hline $10 / 2$ & m & فوت همسر & وضعيت تأهل \\
\hline$r / l$ & $\varepsilon$ & مجرد & \\
\hline 70 & $i r$. & با خانواده & \\
\hline$r V$ & $o \varepsilon$ & باهمسر & تركيب زندكى \\
\hline$\wedge$ & 17 & تنها & \\
\hline v. & $1 \varepsilon$. & مستقل & وضعيت اقتصادى \\
\hline$r$. & 7. & و و وابسته & \\
\hline$r q / 0$ & va & خانه دار & \\
\hline$\varepsilon r$ & $\wedge \varepsilon$ & بازنشسته & وضعيت اشتغال \\
\hline $1 N / 0$ & rV & شاغل & \\
\hline 91 & 197 & مستقل & استقلال در انجام امور \\
\hline r & $\varepsilon$ & متكى به ديخران & زندىى \\
\hline TV & $o \varepsilon$ & بهتر از همسالان & \\
\hline 09 & 111 & همانند همسالان & وضعيت سلامتى فعلى \\
\hline $1 \varepsilon$ & rی & بدتر از همسالان & \\
\hline $1 \varepsilon$ & ru & افسردگى & \\
\hline 7 & ir & 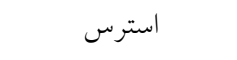 & وضعيت روانشناختى \\
\hline 9 & 11 & اضطراب & \\
\hline v) & $1 \varepsilon r$ & سالم & \\
\hline rt & $\varepsilon \varepsilon$ & يرفشارى خون & \\
\hline$r / / 0$ & $\varepsilon r$ & قلبى عروقى & \\
\hline v & $1 \varepsilon$ & ديابت & وضعيت بيمارى زمينهاى \\
\hline$r M / O$ & $\varepsilon \vee$ & مرد & \\
\hline 7 & ir & 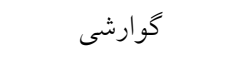 & \\
\hline r & $\varepsilon$ & تنفسى & \\
\hline
\end{tabular}

از زندگى و جدول شماره (r) ادراك از سالمندى و ابعاد آن در سالمندان، جدول شماره (ع) ارتباط معنىدار
جدول شماره (1) مشخصات جامعه شناختى، جدول شماره (Y) توزيع فراوانى و شاخصهاى عددى رضايت 
وضعيت اقتصادى (1 (P=/P)، استقلال در امور روزانه

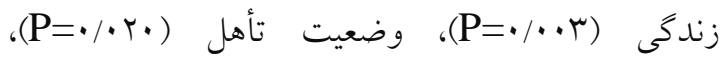

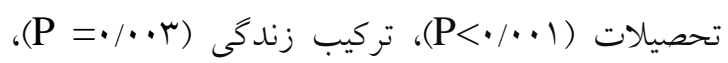
وضعيت سلامتى ( (P</ P)، وضعيت روانشناختى

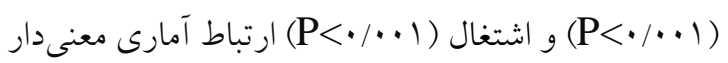
داشته است. متغير اصلى يزوهش يعنى رضايت از زندگى با متغير سن

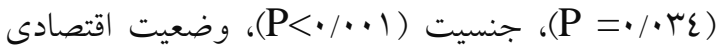

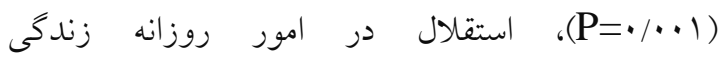

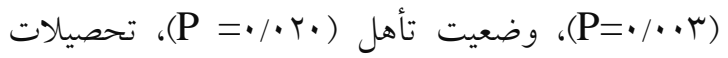
(P<•/・1)

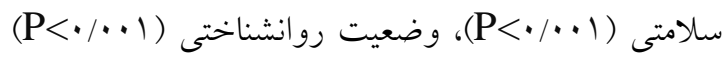
و اشتغال (1 ( P / P) ارتباط آمارى معنى دار داشته است. ليكن اين متغير رضايت از زندگى با متغير وضعيت بيمارى زمينهاى ارتباط آمارى معنى دارى نداشت (
رضايت از زندگى با متغيرهاى جمعيت شناختى و جدول شماره (0) ارتباط معنى دار ادراى از سالمندى با متغيرهاى جمعيت شناختى را ارايه مى كنند.

جدول شماره r: توزيع فراوانى و شاخص هاى عددى رضايت

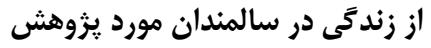

\begin{tabular}{|c|c|c|}
\hline درصد & فر اوانى & رضايت از زندگى \\
\hline $\mathrm{rV} / 0$ & vo & 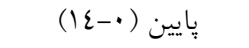 \\
\hline $7 r / 0$ & Iro & بالا (10-7r) \\
\hline $1 \cdots$ & r.. & جمع \\
\hline \multicolumn{2}{|c|}{$10 / r \pm T / r$} & نحراف معيار 土 ميانخين \\
\hline \multicolumn{2}{|c|}{$|\cdot-r|$} & بيشينه-كمينه \\
\hline
\end{tabular}

رضايت از زندكى با متغير وضعيت بيمارى زمينهاى (P=•/1^ع) زندگى با متغير سن ( ع/•/

جدول شماره سا: شاخصهاى عددى ادراك از سالمندى در سالمندان مورد يزوهش

\begin{tabular}{|c|c|c|c|c|}
\hline دامنه نمرات & حداقل - حداكثر & انحراف معيار & ميانغين & ادراك از سالمندى \\
\hline $10-r$ & $1 \varepsilon-0$ & $1 / \wedge$ & $9 / \mu$ & سير ييشرونده \\
\hline $10-r$ & $10-V$ & $1 / T$. & $11 / 1$ & نتايج مثبت \\
\hline 10-r & $10-r$ & $r / .9$ & $1 \cdot / r$ & كنترل مثبت \\
\hline ro-O & $r \mid-\Lambda$ & $T / \varepsilon$ & $10 / \pi$ & نتايج وكتترل منفى \\
\hline $10-r$ & r r & $1 / V$ & $7 / \Lambda$ & واكنش هاى احساسى \\
\hline $10-1 V$ & $T r-\varepsilon r$ & $r / q$ & or $/ \cdot 1$ & نمره كل \\
\hline
\end{tabular}

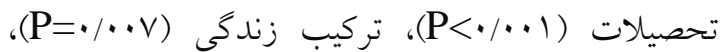
وضعيت سلامتى ( (P> (P)، وضعيت اقتصادى

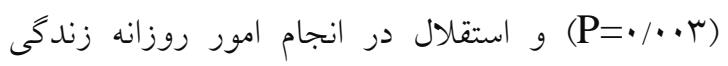
ارتباط معنى دار داشته است. $(\mathrm{P}<$ • / 1)
ادراك از سالمندى با متغير جنسيت ( • (P= (19)، وضعيت

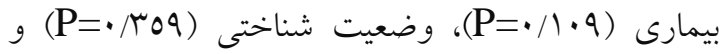

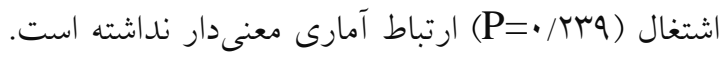

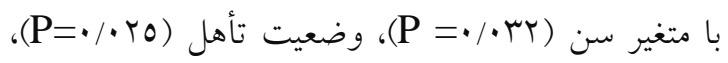




\begin{tabular}{|c|c|c|c|c|}
\hline نتايج آزمون & انحر اف معيار & ميانغين & رضايت از زندگى & \\
\hline $\mathrm{F}=r / 20$ & $r / .7$ & $10 / 0 \varepsilon$ & $7 \varepsilon-7$. & \\
\hline \multirow[t]{2}{*}{$\mathrm{P}=\cdot / \cdot r \varepsilon$} & $r / r)$ & $1 \varepsilon / \Lambda$ & $79-70$ & 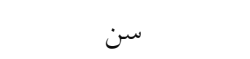 \\
\hline & $r / 9 \varepsilon$ & $\mid \varepsilon / \wedge$ & vo-v. & \\
\hline$F=r / 91$ & $T / Y)$ & $10 / 21$ & متاهل & \\
\hline \multirow[t]{2}{*}{$P=\cdot / r$} & $r / l \varepsilon$ & $1 \varepsilon / \pi q$ & همسرفوت & وضعيت تأهل \\
\hline & $1 / N$ & IENO & مجرد & \\
\hline$* F=\mid r / q \varepsilon$ & $T / I \varepsilon$ & $1 \varepsilon / N T$ & زير دييلم & \\
\hline \multirow[t]{2}{*}{$\mathrm{P}<\cdot / \cdot \cdot 1$} & $r / \cdot r$ & $17 / 00$ & دييلم & تحصيلات \\
\hline & $1 / \cdot$ & $17 / 0$ & دانشخاه & \\
\hline$* F=I T / 9 \varepsilon$ & $T / T \varepsilon$ & $1 \varepsilon / A T$ & باخانو اده & \\
\hline \multirow[t]{2}{*}{$\mathrm{P}<\cdot / \cdot \cdot 1$} & $r / . r$ & $17 / 00$ & باهمسر & تركيب زندگى \\
\hline & $1 / \cdot \cdot$ & $17 / 0$. & تنها & \\
\hline$* F=|7 / 9|$ & $T / \cdot T^{2}$ & $1 \varepsilon / N \varepsilon$ & خانه دار & \\
\hline \multirow[t]{2}{*}{$\mathrm{p}<\cdot / \cdot \cdot 1$} & $r / 10$ & $10 / \cdot 1$ & بازنشسته & وضعيت اشتغال \\
\hline & $1 / 9 \varepsilon$ & $\mid V / \cdot 0$ & شاغل & \\
\hline$* F=11 / \lambda V$ & $1 / 70$ & $\mid r / T V$ & |فسردگى & \\
\hline \multirow[t]{3}{*}{$\mathrm{P}<\cdot / \cdot \cdot 1$} & $r / \cdot r$ & $10 / 21$ & استرس & وضعيت روانشناختى \\
\hline & $1 / 9 T$ & $10 / .0$ & اضطراب & \\
\hline & $r / 10$ & $10 / \pi \Lambda$ & سالم & \\
\hline$t=r / \cdot r$ & $r / 19$ & $10 / r 0$ & مستقل & استقلال در انجام امور \\
\hline $\mathrm{df}=191$ & $1 / 21$ & Ir & و وابسته & روزانه زندكى \\
\hline \multicolumn{5}{|l|}{$\mathrm{P}<\cdot / \cdot r r$} \\
\hline$* F=|T / N|$ & T/T & $17 / 11$ & بهتر از همسالان & \\
\hline \multirow[t]{2}{*}{$\mathrm{P}<. / . \cdot 1$} & $r / \cdot \varepsilon$ & $10 / \pi \varepsilon$ & همانند همسالان & وضعيت سلامتى فعلى \\
\hline & $r / r$. & $|r / N|$ & بدتر از همسالان & \\
\hline $\mathrm{t}=r / r q$ & $T / T q$ & $10 / 71$ & مستقل & \\
\hline $\mathrm{df}=191$ & $1 / M$ & $|\varepsilon / 0|$ & وابسته به ديخران & وضعيت اقتصادى \\
\hline $\mathrm{P}<\cdot / \cdot \cdot 1$ & & & & \\
\hline
\end{tabular}

: مطح معنى دارى (P</.0) است :

ميانخين نمرات رضايت از زندگى در سالمندانى كه زير

دييلم بودند از سالمندانى كه دييلم بودند پِإيينتر بود و و يا با متغير تركيب خانو اده ارتباط معنى دار

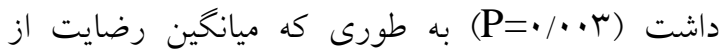

زندكى در سالمندانى كه با خانواده زندكى مى كردند از

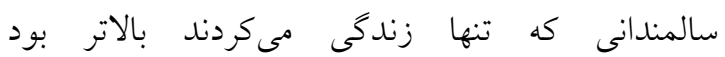

آزمون دو به دو شفه نشان داد كه ميانخين نمرات رضايت

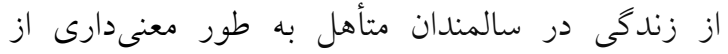
سالمندانى كه همسرانشان فوت كرده و يا از نظر تأهل

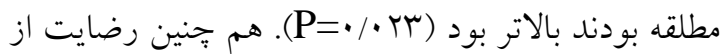
زندگى با متغيرهايى مانند تحصيلات ارتباط معنىدار داشت ( P</.•l) و آزمون دو به دو شفه نشان داد كه 


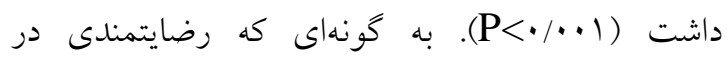

سالمندانى كه افسرده بودند به نسبت در سالمندانى كه به به استرس داشتند (r (P=/P) و يا اضطراب بالايى داشتند

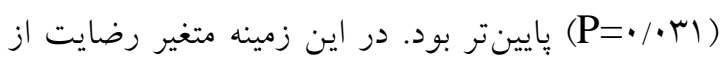
زندكى با متغير وضعيت اشتغال ارتباط معنىدار داشت به اين صورت كه رضايتمندى در سالمندان خانهدار نسبت به سالمندان شاغل پيايينتر ( ( P (P) بود و رضايتمندى در سالمندان بازنشسته از سالمندان شاغل

$$
\text { يايين تر بود ( (P<) }
$$

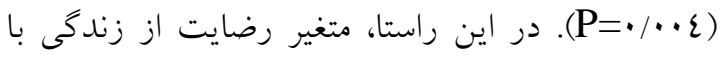

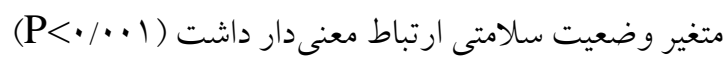
كه بر طبق نتايج آزمون دو به دو، ميانخين رضايت از زندگى به طور معنىدارى در سالمندانى كه وضعيت

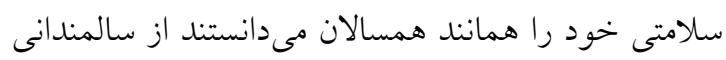
كه وضعيت سلامتى خود را بهتر از همسالان مى بنداشتند

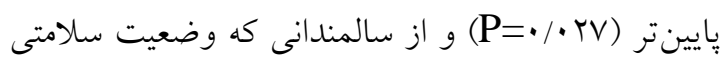
خود را بدتر از همسالان مىينداشتند بالاتر بود

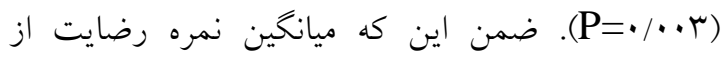
زندگى با متغير وضعيت روانشناختى ارتباط معنىدار

جدول شماره 0: ارتباط بين ادراك از سالمندى در سالمندان مورد مطالعه و مشخصات جمعيت شناختى

\begin{tabular}{|c|c|c|c|c|}
\hline نتايج آزمون & انحر اف معيار & ميانخين & ادراك از سالمندى & \\
\hline$* \mathrm{~F}=\mathrm{r} / 01$ & r/vo & $O r / \varepsilon V$ & $7 \varepsilon-7$. & \multirow{3}{*}{ 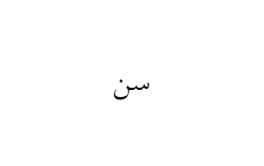 } \\
\hline \multirow[t]{2}{*}{$P=\cdot / \cdot r r$} & $\varepsilon / \uparrow$ & OY/VA & $79-70$ & \\
\hline & $\varepsilon / \varepsilon V$ & $01 / .9$ & Vo-V. & \\
\hline$F=r / v_{0}$ & r/VA & $O r / \varepsilon r$ & متأهل & \multirow{3}{*}{ تأهل } \\
\hline \multirow[t]{2}{*}{$P=. * \cdot r_{0}$} & $\varepsilon / T r$ & $01 / 40$ & همسر فوتى يا مطلقه & \\
\hline & $7 / 19$ & Or/TO & مجرد & \\
\hline$* \mathrm{~F}=\mid\{\tau / 9 r$ & $\varepsilon / 11$ & Or/O9 & زير ديبلم & \multirow{3}{*}{ تحصيلات } \\
\hline \multirow[t]{2}{*}{$\mathrm{P}<\cdot / \cdot 1$} & $r / r$. & $0 \varepsilon / \varepsilon\rceil$ & ديبلم & \\
\hline & T/AV & or/vo & تحصيلات دانشگاهى & \\
\hline$* \mathrm{~F}=0 / \cdot 7$ & $r / \Lambda \Lambda$ & Or/Or & با خانو اده & \multirow{3}{*}{ تركيب زندگى } \\
\hline \multirow[t]{2}{*}{$\mathrm{P}=\cdot / \cdot \cdot \mathrm{V}$} & $r / v \cdot$ & $O Y / \Lambda 1$ & باهمسر & \\
\hline & $\varepsilon / \varepsilon\rceil$ & $0 . / \mu 1$ & تنها & \\
\hline$* F=r 1 / 17$ & $r / \mu q$ & $\mathrm{Or} / \mathrm{O}$. & همانند همسالان & \multirow{3}{*}{ وضعيت سلامتى فعلى } \\
\hline \multirow[t]{2}{*}{$\mathrm{P}<\cdot / \cdot \cdot$} & $r / 20$ & Or/TE & بهتر از همسالان & \\
\hline & $\varepsilon / 77$ & $\varepsilon q / \cdot r$ & بدتر از همسالان & \\
\hline$t=T / r r$ & $r / 97$ & $O H / I T$ & مستقل & استقلال در امور روزانه \\
\hline $\mathrm{df}=191$ & $r / 00$ & $01 / \cdots$ & متكى به ديخران & زندى \\
\hline \multicolumn{5}{|l|}{$\mathrm{P}<\cdot / \cdot \cdot 1$} \\
\hline$t=r / \cdot 7$ & $\varepsilon / 1$. & $O Y / 9 V$ & مستقل & \\
\hline $\mathrm{df}=191$ & $\varepsilon / \iota$ & $0 Y / 97$ & و وابسته به ديخران & وضعيت اقتصادى \\
\hline$P=\cdot / \cdot r$ & & & & \\
\hline
\end{tabular}


رضايت از زندكى در سالمندان شركت كننده در مطالعهى

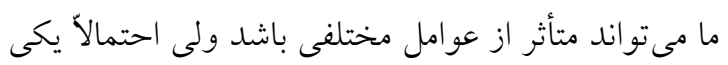

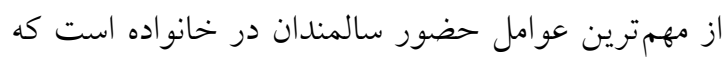

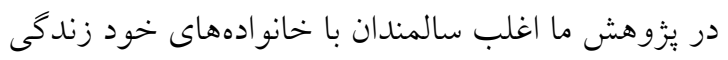

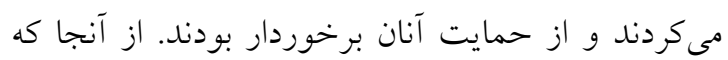

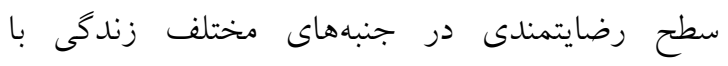

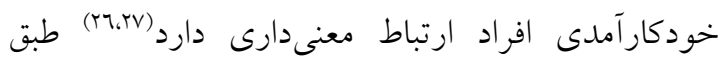

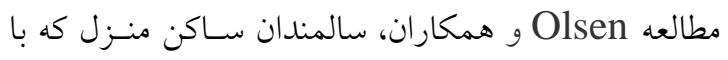
اعضاى خانواده زندگى مى كنند به مراتب نسبت به سالمندان ساكن در سراى سالمندان، داراى رضايت از زندگى و خودكار آمدى و خود مر اقبتى بالاتر بودند (r^). همجينين ميانخين رضايت از زندكى مردان شركت كننده

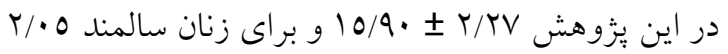

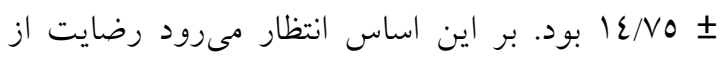

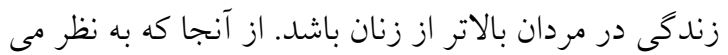

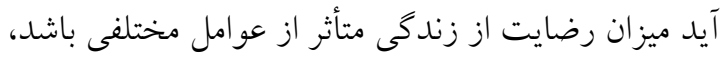
اين تفاوتها ممكن است تحت تأثير معيارهاى انتخاب

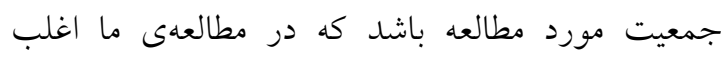
سالمندان جوان انتخاب شده بودند و از استقلال در انجام امور روزانه خود برخوردار بودند و يا تحت الشعاع ابزار

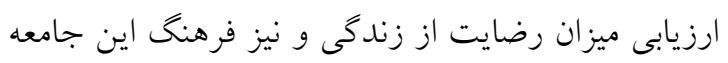

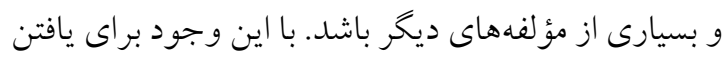

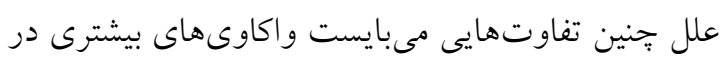

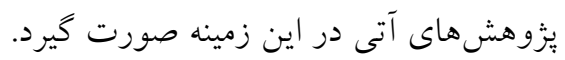

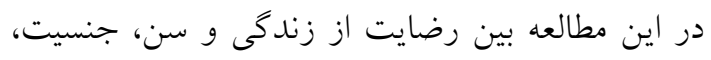

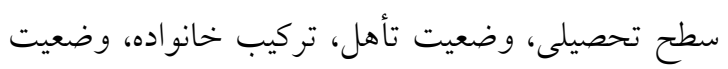
اقتصادى، وضعيت سلامتى، روانشناختى، وضعيت اشتغال و استقلال در امور روزانه زندكى ارتباط معنىدارى وجود

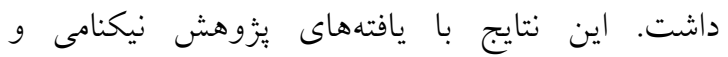

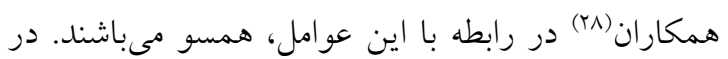
يزوهش نيكنامى افزايش سطح تحصيلات با ارتقاء رفتارهاى بهداشتى و افزايش رضايت از زندكى سالمندان

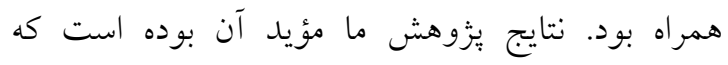
سالمندان شاغل نسبت به سالمندان خانه دار از سطح بالاتر
نتايج آزمون مقايسه دو به دو شفه و ضريب همبستخى نشان داد كه ميانخين نمرات ادراك از سالمندى به طور

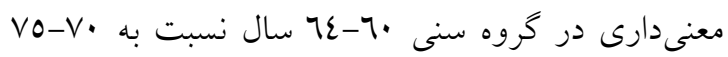

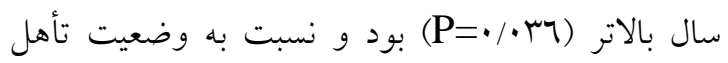

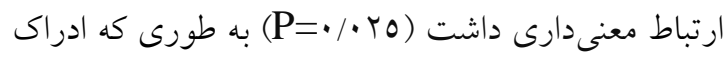
از سالمندى در سالمندانى كه متأهل بودند نسبت به افرادى داري

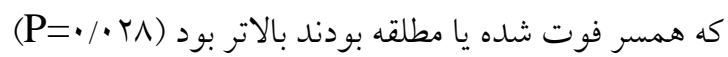

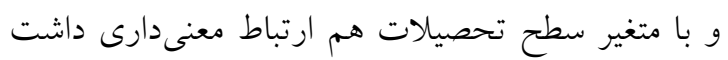
(P<•/./l) به طور معنى دارى در سالمندانى كه زير دييلم بودند نسبت

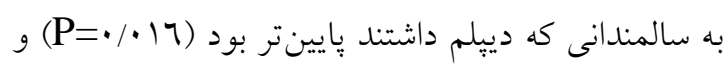

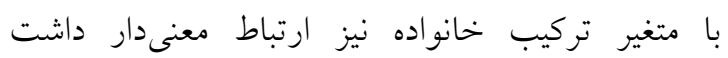

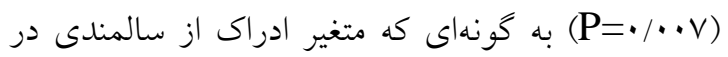
سالمندانى كه با اعضاى خانو اده زندگى مى كردند نسبت

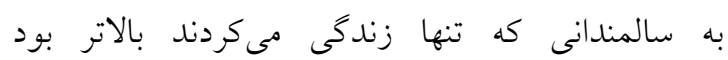
(P=•/・N)

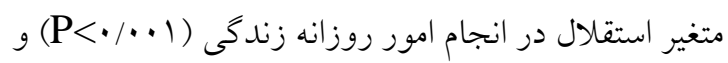

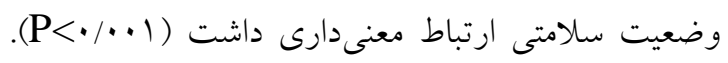

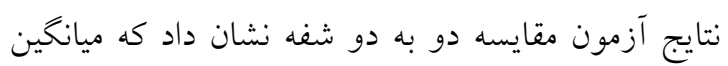

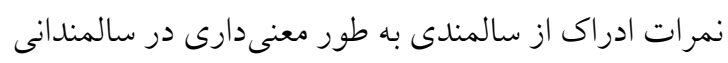

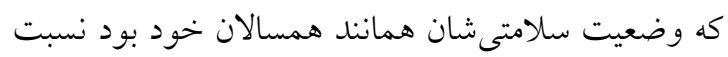
به سالمندانى كه وضعيت سلامتىشان بدتر از همسالان همان

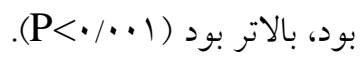

\section{بحث و نتيجه تيرى}

اين مطالعه با هدف بررسى وضعيت سالمندى موفق در بعد رضايت از زندگى و درى از سالمندى در سالمندان مراجعه كننده به مركز بهداشت غرب تهران انجام شد.

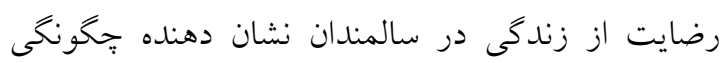

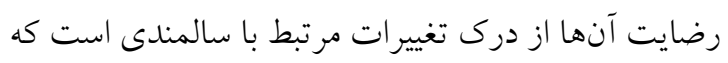
در زندگى آنها رخ مىدهد و ارزيابى شناختى هر فرد از زندكى موفق است. در مطالعهى حاضر بر اساس نتايج حاصل 7r/0 درصد از سالمندان رضايت از زندكى بالاو و

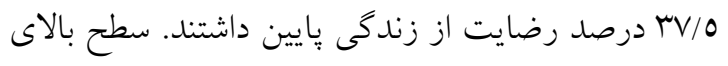


سالمندان دارد. بررسى وضعيت روانشناختى به عنوان

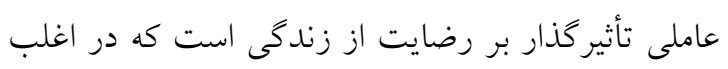

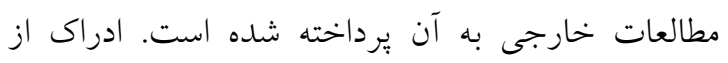
سالمندى با متغير جنسيت، وضعيت بيمارى، وضعيت بهات بردئ

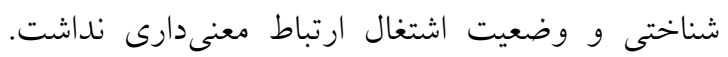

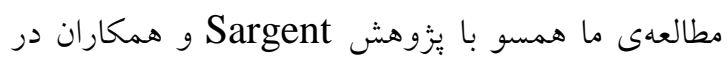

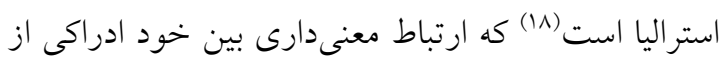
سالمندى با متغير هاى مذكور نداشت اما با ديخر متغيرهاى

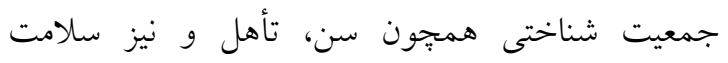
جسمانى و عملكرد شناختى ارتباط معنىدار بود. هم:جنين تحقيق ما همراستا با مطالعهى Cramm و

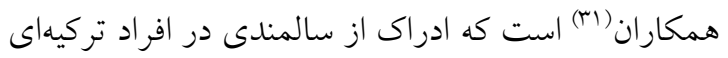
و هلندى ساكن كشور هلند را متأثر از فرهنخ، سطح تحصيلات و سطح سلامتى كزارش نمودند. در اين مطالعه

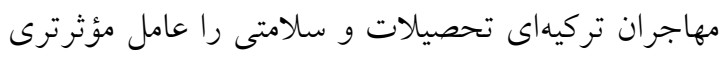
براى ادراى مثبت از سالمندى مىدانستند. سالمندان

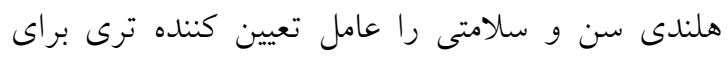

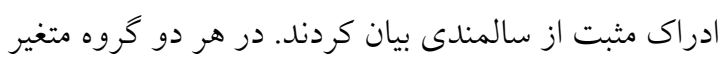

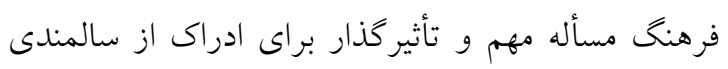

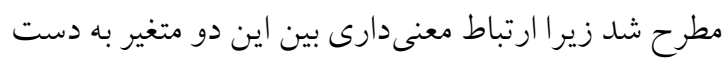

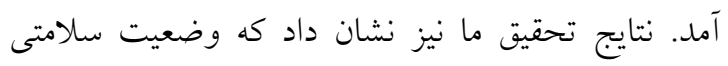

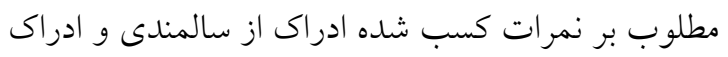
مثبت تر از سالمندى مؤثر است. به طورى كه وضعيت سلامتى در دوران قبل از سالمندى و ظرفيت عملكردى استى

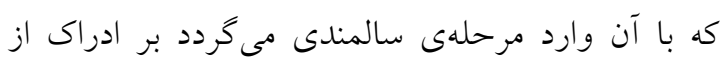

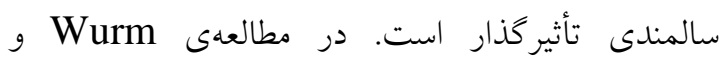

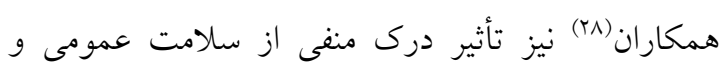
عملكرد جسمانى در فرد سالمند، تضعيف كننده ادراى

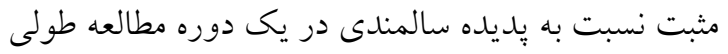

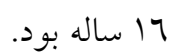
در مطالعهى Choi و همكاران(rr) نيز ارتباط معنىدارى بين سالمندى موفق با وضعيت سلامتى و كيفيت زندگى (حتى در بعد فشارهاى روانى و استرس) در سالمندان

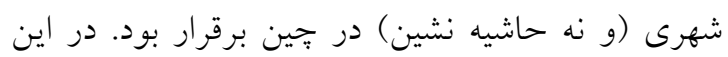

رضايت از زندكى برخوردار هستند. اين احتمال هست كه

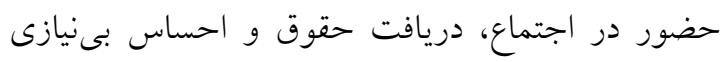

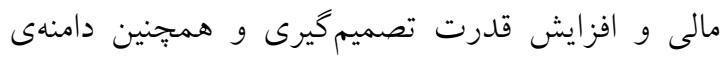

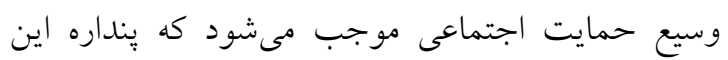
سالمندان مثبتر و رضايت از زيت زندكى بالاترى داشته

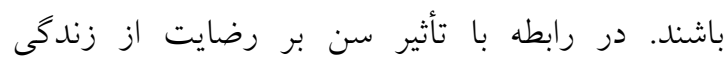
Rodrigers كردند به اين ترتيب كه با افزايش سن، ادراك افراد از سالمندى، سلامتى درى شده، عملكرد و نيز رضايتمندى

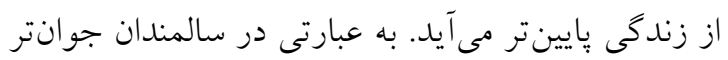
رضايت از زندگى بيشتر است تا سنين بالاتر و بيرتر (T9).

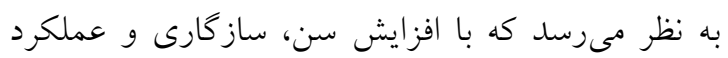

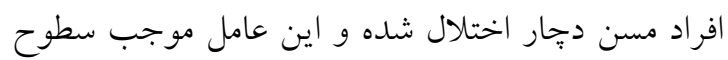

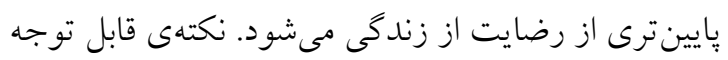

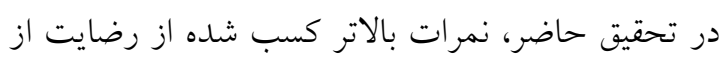

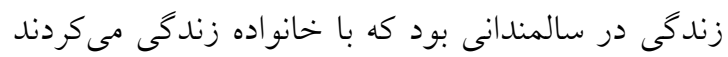

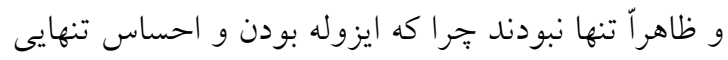

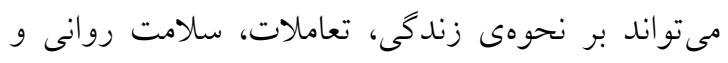

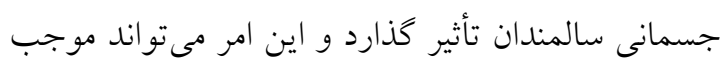

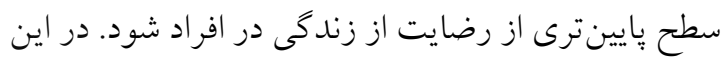

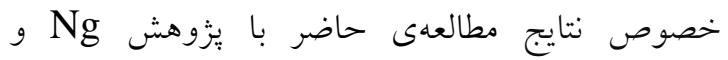

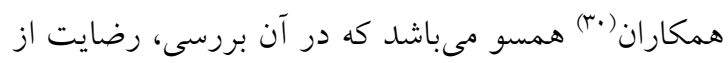

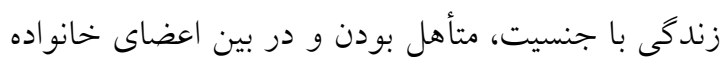

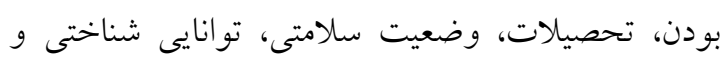
وضعيت اقتصادى ارتباط آمارى معنى دارى داشت. يافتهاى مطالعهى ما نشان داده است كه هر جه سالمندان وضعيت سلامتى خود را مطلوب ارزيابى كند و در رابطه با امور شخصى خود از استقلال عمل بالاترى برخوردار

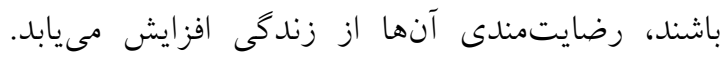

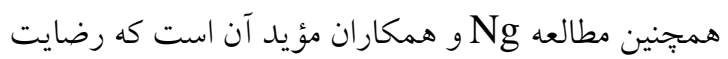

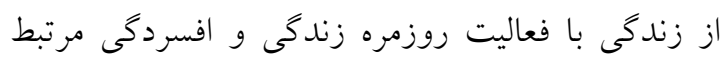
است. در مطالعه ما نيز رضايت از زندكى در سالمندانى كه

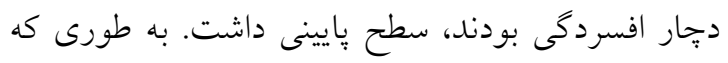

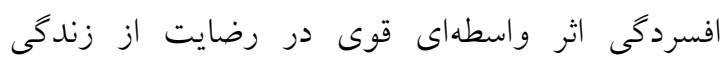


سنى ديخر سالمندان و با تأكيد بر ارتباط اين دو مؤلفه تأثير گذار بر سالمندى موفق با جنس، تحصيلات، تأهل، استقلال در امور روزانه زندگى و وضعيت سلامتى سالمندان صورت گيرد تا يايهاى براى برنامه ريزىهاى مبتنى بر شواهد علمى جامع در يديله سالمندى سالم و موفق باشد. بنابراين در راستاى بيشنهاد براى كاربرد يافته ها، توصيه مى گردد كه مطالعات كيفى و بررسى نظرات و ديدگاههاى سالمندان، تبين عميقتر و زرفترى را از مغهوم سالمندى موفت نشان داده و بر نخاه جند بعدى به سالمندان موفق تأكيد نمايد.

تعارض منافع: هيج گونه تعارض منافعى از سوى نويسند گان گزارش نشده است.

\section{تقلهير و تشك}

از تمامى سالمندان مراجعه كننده به مركز بهداشت غرب تهران كه صبور انه با ما همكارى كردند و همجينين كاركنان اين مركز كه با همكارى بىشائبه خود موجب اشتياق ما در انجام اين يروزه بودند، كمال تشكر را داريم. هم:جنين از حامى مالى اين طرح از سوى معاونت محترم تحقيقات و

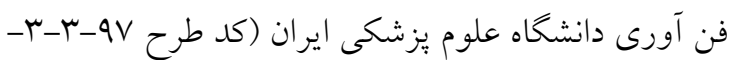
1 ا ( ) جهت انجام اين مطالعه قدردانى مى گردد.
خصوص حتى سالمندانى كه مبتلا به سرطان بوده و تحت

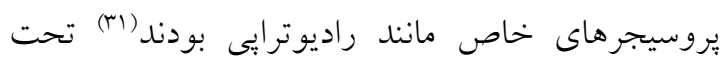
تنشهاى بسيارى قرار مى گيرند كه مىتواند سالمندى موفق آنها را كه به نحوى به كيفيت زندكى آنان از جنبه هاى روانى كره خورده را تحت الشعاع قرار دهد. هم جنين اين وضعيت در سالمندان با شرايط دشوار همجِون مبتلا بودن به سرطان يستان، جر احى هاى شكمى و جراحى قلب باز صادق بوده(rr-rV) و با توسل به مداخلات و و رويكردهاى غيردارويى به سطحى از سامتى مطلوب سالمندى موفق دست يافته بودند. به طورى كه سالمندان با امتياز بالاتر سالمندى موفق از سطح بالاى كيفيت زندكى و سطح سالامتى و سطح بالاى فعاليت فيزيكى برخوردار بودند. مشابه بودن نتايج يزوهش مؤيد اهميت درك مثبت از سالمندى و ارتباط آن با مؤلفه رضايت از زندگى است كه احتمالاً به نحوى مىتواند بر كيفيت زندكى و سالامت عمومى افراد تأثير خذار باشد.

با توجه به اين كه بيشتر نمونههاى يزوهش حاضر از ميان سالمندان جوان ( • VO- سال) بر گزيده شده بودند و درصد قابل توجهى از واحدهاى مورد يزوهش داراى رضايت از زندگى مطلوب بودند و درى مثبت و مطلوبى از سالمندى خود داشتند و با عنايت به اين كه رضايت از زندگى و درى از سالمندى از مؤلفهاى تأثير گذار سالمندى موفت هستند، ضرورى است بيزوهشهاى بعلى در كروههاى

\section{References}

1. Azadchehr M, Rahgozar M, Karimloo M, Adib Haj Bageri M. To identify some factors effective on survival of the elderly living in nursing home using Copula Competing Risk Model: Bayesian approach. Journal of Health Promotion Management. 2014;3(4):46-55.

2. Beard J, Officer A, Cassels A. World report on ageing and health. Geneva: World Health Organization, 2015. 2016.

3. Mohamadi S,Yazdani charati J,Mousavi Nasab Sayyed N. Factors Affecting Iran's Population Aging, 2016. Journal of Mazandaran University of Medical Sciences 2017; 27 (155): 71-8. [Persian]

4. Schneider G, Driesch G, Kruse A, Wachter M, Nehen H-G, Heuft G. What influences selfperception of health in the elderly? The role of objective health condition, subjective well-being and sense of coherence. Arch Gerontol Geriatr. 2004;39(3):227-37.

5. Pruchno RA, Wilson-Genderson M, Rose M, Cartwright F. Successful aging: Early influences and contemporary characteristics. The Gerontologist. 2010;50(6):821-33.

6. Zacher H, Chan F, Bakker AB, Demerouti E. Selection, optimization, and compensation strategies: Interactive effects on daily work engagement. J Vocat Behav. 2015;87:101-7.

7. Rowe JW, Kahn RL. Successful aging. The Gerontologist. 1997;37(4):433-40. 
8. Ouwehand C, de Ridder DT, Bensing JM. A review of successful aging models: Proposing proactive coping as an important additional strategy. Clinical psychology review. 2007;27(8):87384.

9. Willcox DC, Willcox BJ, Sokolovsky J, Sakihara S. The cultural context of "successful aging" among older women weavers in a northern Okinawan village: The role of productive activity. $J$ Cross Cult Gerontol. 2007;22(2):137-65.

10. Motamedi A. The role of life events on successful aging. Journal of Social Sciences and Humanities of Shiraz University. 2005; 4(45): 189-203. [Persian]

11. Ozer M. A study on the life satisfaction of elderly individuals living in family environment and nursing homes. Turkish Journal of Geriatrics. 2004;7(1):33-6.

12. Lyyra T-M, Törmäkangas TM, Read S, Rantanen T, Berg S. Satisfaction with present life predicts survival in octogenarians. Journals Gerontol B Psychol Scie Soc Sci. 2006;61(6):P319-P26.

13. Carr A. Positive psychology: The science of happiness and human strengths: Routledge; 2013.

14. Sheikhi M, Ali Hh, Ahadi H, Sepah Mm. Psychometric properties of satisfaction with life scale. 2011.

15. Hultell D, Gustavsson JP. A psychometric evaluation of the Satisfaction with Life Scale in a Swedish nationwide sample of university students. Personality and Individual Differences. 2008;44(5):1070-9.

16. Sadegh Moghadam L, Foroughan M, Mohammadi F, Ahmadi F, Farhadi A, Nazari S, et al. Aging perception in older adults. Iranian Journal of Ageing. 2016;10(4):202-9. [Persian]

17. Caldas CP, Berterö CM. Living as an oldest old in Rio de Janeiro: the lived experience told. Nurs Sci Q. 2007;20(4):376-82.

18. Sargent-Cox KA, Anstey KJ, Luszcz MA. Longitudinal change of self-perceptions of aging and mortality. Journals Gerontol B Psychol Scie Soc Sci. 2013;69(2):168-73.

19. Borhaninejad V, Kazazi L, Haghi M, Chehrehnegar N. Quality of life and its related factors among elderly with diabetes. Salmand, Iranian Journal of Ageing. 2016; 11(4): 162-73. [Persian]

20. Nascimento RGd, Cardoso RdO, Santos ZNLd, Pinto DdS, Magalhães CMC. The perception of elderly riverside residents of the Amazon region: the empirical knowledge that comes from rivers. Revista Brasileira de Geriatria e Gerontologia. 2016;19(3):429-40.

21. Freitas MCd, Queiroz TA, Sousa JAVd. The meaning of old age and the aging experience of in the elderly. Rev Esc Enferm USP. 2010;44(2):407-12.

22. Kim SH. Older people's expectations regarding ageing, health-promoting behaviour and health status. J Adv Nurs. 2009;65(1):84-91.

23. Ayyash-Abdo H, Alamuddin R. Predictors of subjective well-being among college youth in Lebanon. The Journal of Social Psychology. 2007;147(3):265-84.

24. Kearney PM, Cronin H, O'regan C, Kamiya Y, Savva GM, Whelan B, et al. Cohort profile: the Irish longitudinal study on ageing. Int J Epidemiol. 2011;40(4):877-84.

25. Wood V, Wylie ML, Sheafor B. An analysis of a short self-report measure of life satisfaction: Correlation with rater judgments. J Gerontol. 1969;24(4):465-9.

26. Doménech-Betoret F, Abellán-Roselló L, Gómez-Artiga A. Self-efficacy, satisfaction, and academic achievement: the mediator role of Students' expectancy-value beliefs. Front Psychol. 2017;8:1193.1-12.

27. Machmud S. The Influence of Self-Efficacy on Satisfaction and Work-Related Performance. International Journal of Management Science and Business Administration. 2018;4(4):43-7.

28. Niknamy M, Namjoo A, Baghaee M, Atrkar Roshan Z. Survey the Relationship between Life Satisfaction and Health Behaviors in Elderly People Referring to Active Retire mental Centers. Journal of Guilan University of Medical Sciences, 2010;19(73): 46-54. [Persian]

29. Rodgers V, Neville S, La Grow S. Health, functional ability and life satisfaction among older people 65 years and over: a cross-sectional study. Contemporary nurse. 2017;53(3):284-92.

30. Ng ST, Tey NP, Asadullah MN. What matters for life satisfaction among the oldest-old? Evidence from China. PloS one. 2017;12(2):e0171799.

31. Cramm JM, Nieboer AP. Positive ageing perceptions among migrant Turkish and native Dutch older people: a matter of culture or resources? BMC geriatrics. 2017;17(1):159.

32. Choi M, Lee M, Lee MJ, Jung D. Physical activity, quality of life and successful ageing among community-dwelling older adults. Int nurs rev. 2017;64(3):396-404. 
33. Haghparast A, Hashemi B, Eivazi MT. Influence of compensator thickness, field size, and off-axis distance on the effective attenuation coefficient of a cerrobend compensator for intensitymodulated radiation therapy. Medical Dosimetry. 2013;38(1):25-9.

34. Bastani F, Hosseiny RS, Baniasad M, Haghni H. Investigation of general health in female care givers of elderly people with alzheimer. Iranian Journal of Ageing. 2010;5(3): 43-51. [Persian]

35. Basiri M, Bastani F, Haghani H, Rahmatnejad L. Effect of Slow-Stroke Back Massage on Anxiety of Older Women With Breast Cancer Undergoing Chemotherapy'. Journal of Client-Centered Nursing Care. 2016;2(2):115-22. [Persian]

36. Kheyri A, Bastani F, Haghani H. Effects of reflexology on sleep quality of elderly women undergoing abdominal surgery. Journal of Client-Centered Nursing Care. 2016;2(1):11-8. [Persian]

37. Bastani F, Hajizadeh S, Saatchi K, Haghani H. Comparing the effect of acupressure and cryotherapy on the pain caused by removal of chest drain tube in the elderly patients undergoing open heart surgery'. Journal of Client-Centered Nursing Care. 2016;2(1):37-52. [Persian] 